\title{
EFFECT OF Sr, Ti AND B ADDITIONS AS POWDER AND A PRELIMINARY ALLOY ON ELONGATION AISI9Mg ALLOY
}

\author{
${ }^{1}$ Tomasz LIPIŃSKI, ${ }^{2}$ Anna KIEŁBUS \\ ${ }^{1}$ University of Warmia and Mazury in Olsztyn, Olsztyn, Poland, EU, tomaszlipinski.tl@gmail.com \\ ${ }^{2}$ Cracow University of Technology, Kraków, Poland, EU, anna.kielbus@pk.edu.pl
}

https://doi.org/10.37904/metal.2021.4264

\begin{abstract}
Aluminum alloys as hypoeutectic AISi9Mg alloy have at microstructure a granular and acicular $\beta$ phase, with $\alpha$ phase as matrix. The hard, irregular, often pointed $\beta$ phase is responsible for the poor mechanical properties of said alloy. This composition is responsible for Al-Si alloy's low strength parameters. This study presents the results of modification of an AISi9Mg alloy with strontium, boron and titanium in different ranges produced as a melted modifier added as powders and as rod. The influence of the analyzed additions on the elongation of the silumin was presented in graphs. The used treatments of a hypoeutectic AISi9Mg alloy improved the alloy's properties. The results of the tests indicate that the elongation of the modified alloy are determined by the sequence in which the components are introduced to the alloy.
\end{abstract}

Keywords: Al-Si alloy, silumin, modification, mechanical properties

\section{INTRODUCTION}

Aluminum alloys have excellent castability, good weldability, good thermal conductivity, high strength at elevated temperatures and excellent corrosion resistance for these reasons, they have found wide application. The microstructure and mechanical properties of $\mathrm{Al}-\mathrm{Si}$ alloys may be altered through improvement by modification, heat processing etc. [1]. One of the most popular modification methods involves the use of chemical elements and compounds. Sodium and strontium are the most commonly used modifiers in subeutectic silumins. Strontium permanently modifies silumins, while sodium shapes their structure over a set period of time [2]. There are other chemical compositions to improvement its properties. These include, but are not limited to, boron and titanium [3-6]. Addition of sodium or strontium and other elements modifiers in AlSi cast alloys have been found to improve mechanical properties considerably [7]. The modification behavior of Al-Si alloy was first studied in $1920 \mathrm{by} \mathrm{Pacz}$, who shows that the additions of sodium or its salts to the molten alloys leads to structural modification during solidification and hence, to a considerable improvement in its mechanical properties [8]. In 1966 Thiele and Dunkel showed that the effects of strontium on such alloys are similar and longer-lasting than those of sodium [9]. However, in recent years it has been established that the technological properties of aluminum - silicon alloys can be enhanced by adding modifiers and by applying suitable thermal treatments [10-13], technological [14], repeated modification [15] and others [16].Mechanical properties of $\mathrm{Al}-\mathrm{Si}$ cast alloys depend not only on chemical composition but, more importantly, on microstructural features such as morphologies of dendritic $\alpha-\mathrm{Al}$, eutectic Si particles and other intermetallics that present in the microstructure. The porosity of casting alloys also affects their properties $[17,18]$. Especially tensile strength, elongations and hardness are important reasons for increasing applications of this alloy system. 
Despite the availability of a wide range of technologies enhancing the usable properties of $\mathrm{Al}-\mathrm{Si}$ alloys, modification continues to be the most popular method. Recent years have witnessed various research studies attempting to change silumin structure with the use of the temperature gradient. A method for modifying silumin structure has been developed with the involvement of a modifier obtained by rapid silumin cooling. The chemical composition of the modifier is identical or similar to that of a processed alloy. Despite numerous studies into the improvement of silumin properties, modification methods involving chemical elements and compounds deliver the most cost-effective results. The research of inoculation and modification of eutectic and hypoeutectic aluminum-silicon alloys by sodium, strontium, antimony and other additions in the metallurgic process have been already analyzed and described by numerous authors [1,2,5,7,19]. At present time strontium is the most frequently used in the Aluminum alloy industry because it is easy to handle, has a good modification rate, a long incubation time and a low fading effect. The results of a number of studies boil down to the description of the effect of the crystallization process on the microstructure [20], and then the microstructure on the mechanical properties of alloys $[1,2,4]$. However, the most reasonable for practical reasons is the study of mechanical properties. The goal of metal alloys research is to obtain the highest quality possible. The goal is to achieve this effect while maintaining favorable economic conditions by obtaining the lowest possible alloy price as well as reducing research costs. For the above reasons, statistical methods and computer techniques are often used in research. The main aim of the present investigation was to evaluate influence of strontium, boron and titanium in different ranges produced as a melted modifier added as powders and as rod melted with Al on elongation of AISi9Mg alloy.

\section{METHODS}

The experimental material was AISi9Mg alloy which was regarded as representative of hypo-eutectic silumin. The alloy was obtained from industrial piglets. The alloy was melted in ceramic crucible an electric furnace, and the modification process was carried out with $\mathrm{Sr}$, $\mathrm{Ti}$ and $\mathrm{B}$ additions. The melting was carried out in two series applying fullfactorial experiment $\left(2^{3}\right)$ for three independent variables (Table 1). In the first series, the additives were introduced into the alloy in the form of a powder mix in accordance with the test plan. In the second series, in the form of a rod created by melting the amount of individual components appropriate for a given study plan point and aluminum. At each point in the research plan, the total amount of additives in the preliminary alloy accounted for about $10 \%$. The same research plan was used to compare the effectiveness of silumin treatment in both series. For the second research series, the quantity of preliminary alloy was introduced into the alloy in an amount ensuring the addition of the same amount of individual additives as in the first series. The alloy was modified at a temperature of $800{ }^{\circ} \mathrm{C}$ for 6 minutes. Cylindrical samples, $8 \mathrm{~mm}$ in diameter and $75 \mathrm{~mm}$ in length, were poured into dry sand molds. The elongation test was performed on a specimen with a length-to-diameter ratio of 5:1 in the ZD-30 universal tensile tester. An elongation test was performed on two samples, $6 \mathrm{~mm}$, for each melting point, according to standard PN-EN ISO 6892-1:2016-09 "Metallic materials. Tensile testing. Method of test at ambient temperature". The equation (1) was introduced for received plan of investigations the figure of equation of regress. The modifier was prepared by mixing its components (see equation (1)) in proportions indicated in the experimental plan.

$\hat{y}=b_{0}+b_{1} x_{1}+b_{2} x_{2}+b_{3} x_{3}+b_{12} x_{1} x_{2}+b_{13} x_{1} x_{3}+b_{23} x_{2} x_{3}+b_{123} x_{1} x_{2} x_{3}$

where: $x_{i}$ - factor $(\mathrm{Sr}, \mathrm{Ti}, \mathrm{B}) ; b_{0}, b_{i}, b_{i j}, b_{i j k}-$ equation coefficients.

The results were analyzed mathematically, which enabled to formulate the factor equation for three variables, for the parameters studied, at the level of significance $\alpha=0.05$. The adequacy of the above mathematical equation was verified using the Fisher criterion for $p=0.05$. 
Table 1 Level of variables

\begin{tabular}{|c|c|c|c|c|c|}
\hline Factor & Variable & Primary level (\%) & $\begin{array}{c}\text { Range of } \\
\text { changes (\%) }\end{array}$ & $\begin{array}{c}\text { Higher level } \\
(\%)\end{array}$ & $\begin{array}{c}\text { Lower level } \\
(\%)\end{array}$ \\
\hline $\mathrm{x}_{1}$ & $\mathrm{Sr}$ & 0.04 & 0.02 & 0.06 & 0.02 \\
\hline $\mathrm{x}_{2}$ & $\mathrm{Ti}$ & 0.1 & 0.05 & 0.05 & 0.15 \\
\hline $\mathrm{x}_{3}$ & $\mathrm{~B}$ & 0.04 & 0.02 & 0.06 & 0.02 \\
\hline
\end{tabular}

\section{RESULTS}

The average chemical composition of the tested AlSi9Mg is presented in Table 2.

Table 2 Real chemical composition of the tested AISi9Mg (wt\%)

\begin{tabular}{|c|c|c|c|c|c|c|c|c|c|c|}
\hline Element & $\mathbf{S i}$ & $\mathbf{M g}$ & $\mathbf{M n}$ & $\mathbf{N i}$ & $\mathbf{C r}$ & $\mathbf{F e}$ & $\mathbf{C u}$ & $\mathbf{Z n}$ & $\mathbf{T i}$ & $\mathbf{A l}$ \\
\hline Content & 9.24 & 0.34 & $<0.005$ & 0.003 & 0.05 & 0,15 & 0.03 & 0.007 & 0.001 & balance \\
\hline
\end{tabular}

Elongation of the AISi9\%Mg alloy treated with mixture consisting of $\mathrm{Sr}, \mathrm{Ti}$ and $\mathrm{B}$ compounds as a powder shows on Figures 1-6. The analysis of elongation shows that the greatest benefits were achieved after AIS9Mg alloy treatment with powder of $0.06 \mathrm{wt} \% \mathrm{Sr}, 0.05 \mathrm{wt} \% \mathrm{Ti}$ and $0.06 \mathrm{wt} \% \mathrm{~B}$ which substantially improved alloy properties.

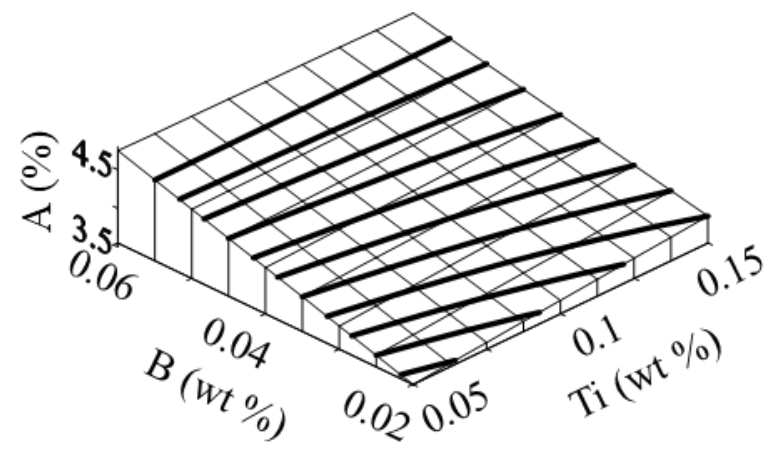

Figure 1 Elongation of AISi9Mg alloy with $B$ within range $\langle 0.02,0.06>(w t \%)$ and Tiwithin range $<0.05,0.15>$ (wt\%) for $\mathrm{Sr}=0.06 \mathrm{wt} \%$

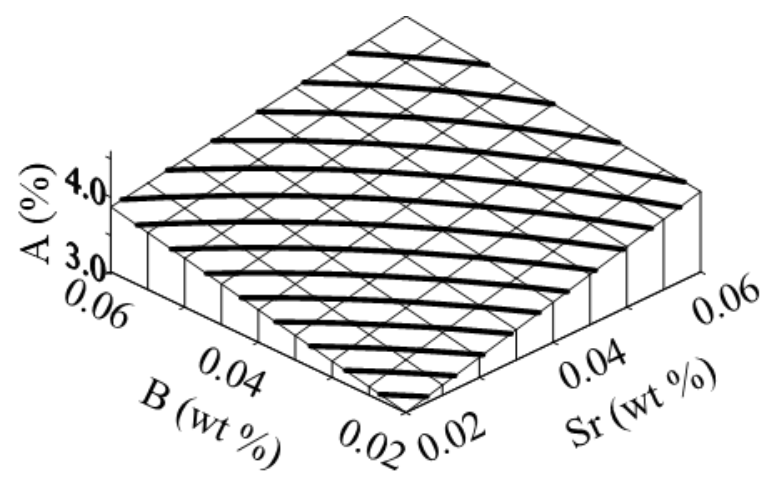

Figure 3 Elongation of AISi9Mg alloy with $\mathrm{Sr}$ within range $<0.02,0.06>(\mathrm{wt} \%)$ and $\mathrm{B}$ within range $<0.02,0.06>(\mathrm{wt} \%)$ for $\mathrm{Ti}=0.15 \mathrm{wt} \%$

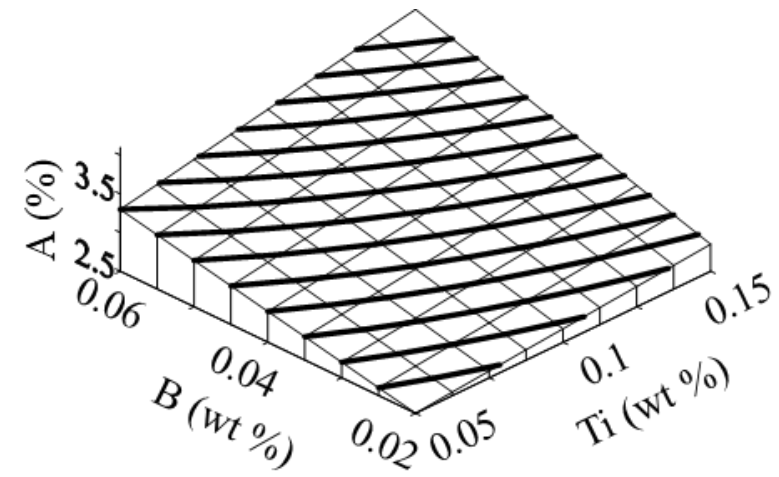

Figure 2 Elongation of AISigMg alloy with $B$ within range $<0.02,0.06>(w t \%)$ and Tiwithin range $<0.05,0.15>(w t \%)$ for $\mathrm{Sr}=0.02 \mathrm{wt} \%$

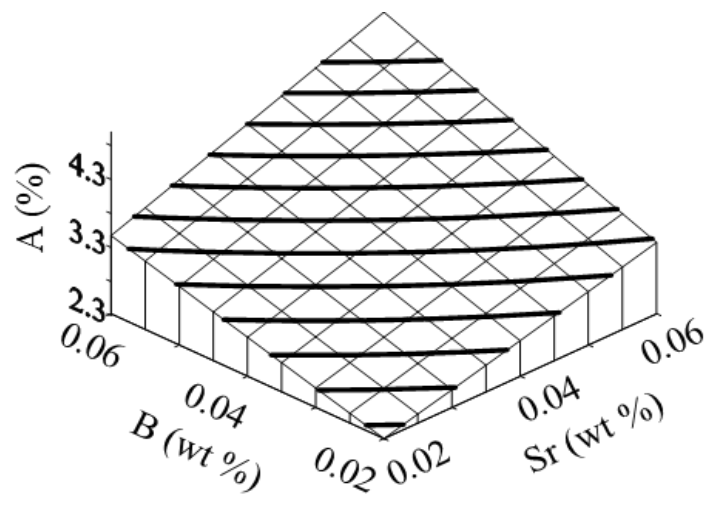

Figure 4 Elongation of AlSi9Mg alloy with Sr within range $<0.02,0.06>(w t \%)$ and $\mathrm{B}$ within range $<0.02,0.06>(\mathrm{wt} \%)$ for $\mathrm{Ti}=0.05 \mathrm{wt} \%$ 


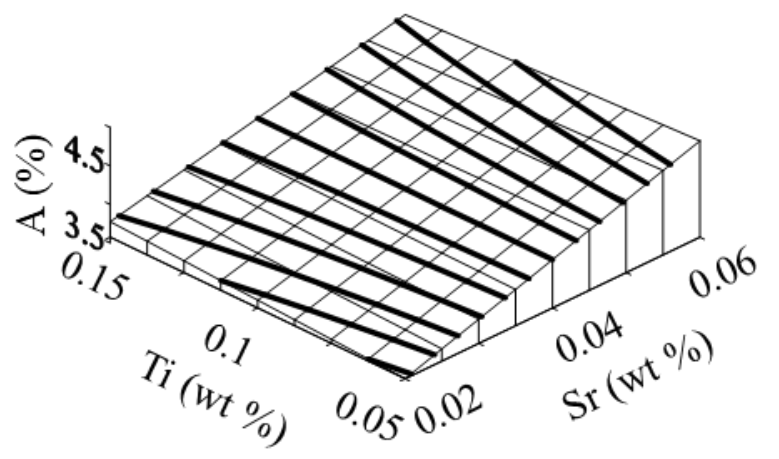

Figure 5 Elongation of AISi9Mg alloy with Sr within range $<0.02,0.06>(w t \%)$ and

Tiwithin range $<0.05,0.15>(w t \%)$ for $B=0.06 w t \%$

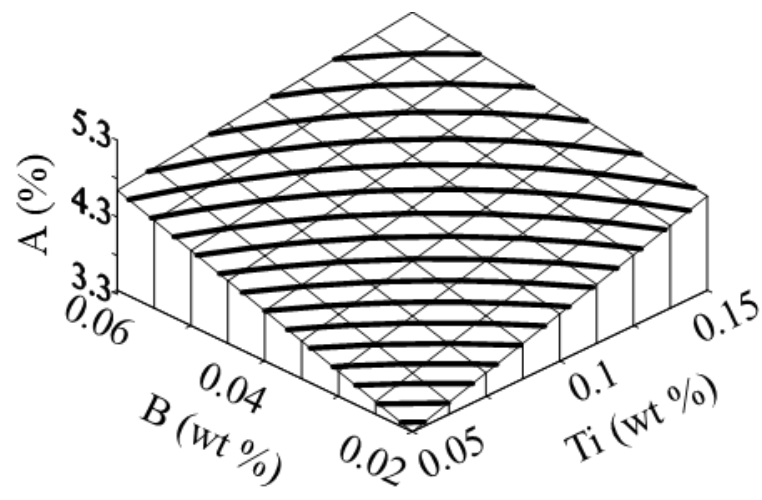

Figure 7 Elongation of AISi9Mg alloy with $B$ within range $<0.02,0.06>(w t \%)$ and Tiwithin range $<0.05,0.15>(w t \%)$ for $\mathrm{Sr}=0.06 \mathrm{wt} \%$

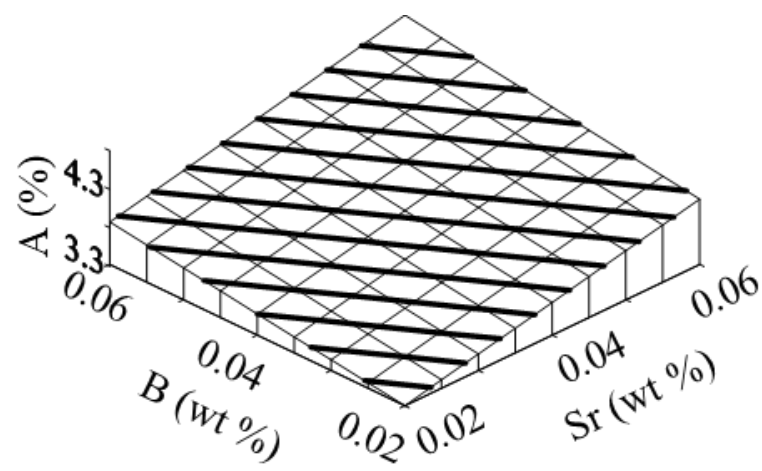

Figure 9 Elongation of AISi9Mg alloy with $\mathrm{Sr}$ within range $\langle 0.02,0.06\rangle$ (wt\%) and $B$ within range $\langle 0.02,0.06>(w t \%)$ for $\mathrm{Ti}=0.15 \mathrm{wt} \%$

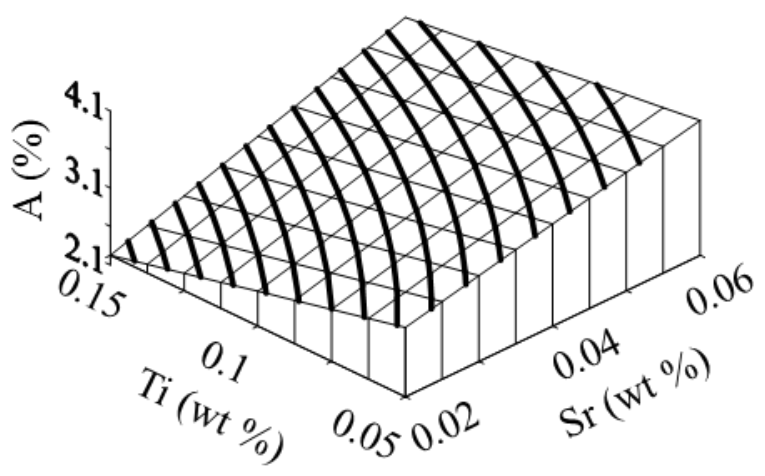

Figure 6 Elongation of AlSi9Mg alloy with $\mathrm{Sr}$ within range $<0.02,0.06>(\mathrm{wt} \%)$ and Tiwithin range $<0.05,0.15>(w t \%)$ for $B=0.02 w t \%$

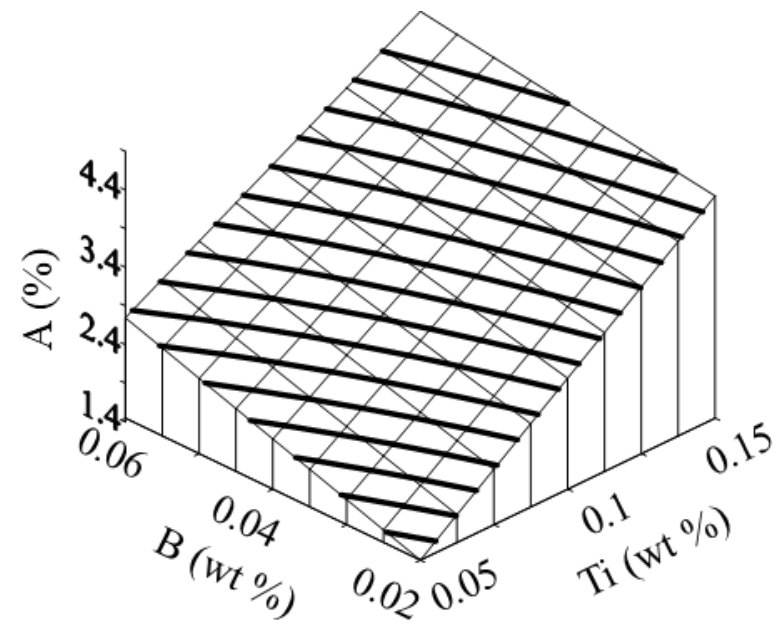

Figure 8 Elongation of AlSi9Mg alloy with $B$ within range $\langle 0.02,0.06>(w t \%)$ and Tiwithin range $<0.05,0.15>(w t \%)$ for $\mathrm{Sr}=0.02 \mathrm{wt} \%$

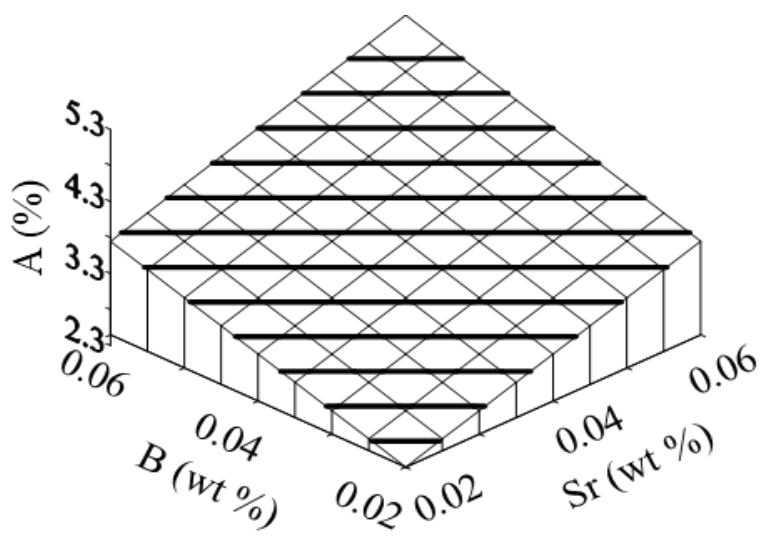

Figure 10 Elongation of AISi9Mg alloy with $\mathrm{Sr}$ within range $<0.02,0.06>$ (wt\%) and $\mathrm{B}$ within range $<0.02,0.06>(\%)$ for $\mathrm{Ti}=0.05 \mathrm{wt} \%$ 
After treatment alloywith a constant content of $\mathrm{Sr}=0.06 \mathrm{wt} \%$ as a powder boron has a greater effect on the increase in elongation then Ti (Figure 1). For the same range of strontium and about $0.06 \mathrm{wt} \%$ boron influence of titanium is imperceptible. The elongation of the AISi9Mg alloy treated with mixture consisting of $\mathrm{Sr}$, $\mathrm{Ti}$ and $\mathrm{B}$ compounds melted with $\mathrm{Al}$ as a rod shows on Figures 7-12.Generally, comparing the elongation after treatment AISi9Mg alloy with the same amounts of $\mathrm{Sr}$, Ti and B introduced into the alloy in the form of powder (series I) and in the form of a preliminary alloy $\mathrm{Sr}$, $\mathrm{Ti}$ and B with $\mathrm{Al}$ (rod) (series II) made by melting the componentmixtures and aluminum in a proportion about 1:10, a higher elongation was found after treatment Al-Si alloy with preliminary alloy.

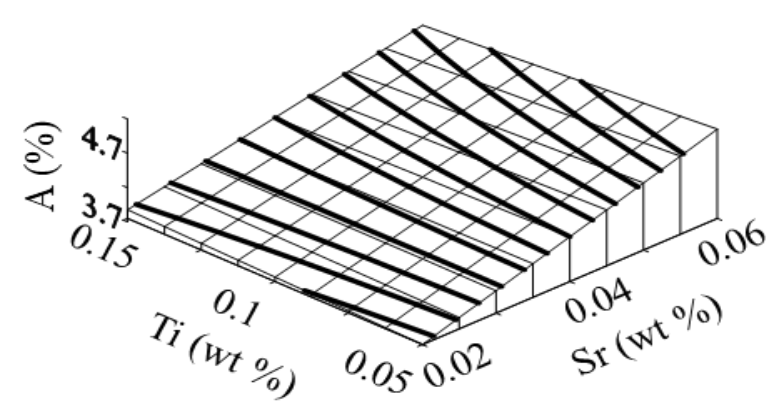

Figure 11 Elongation of AISi9Mg alloy with Sr within range $<0.02,0.06>(w t \%)$ and Ti within range $\langle 0.05,0.15\rangle(w t \%)$ for $\mathrm{B}=0.06 \mathrm{wt} \%$

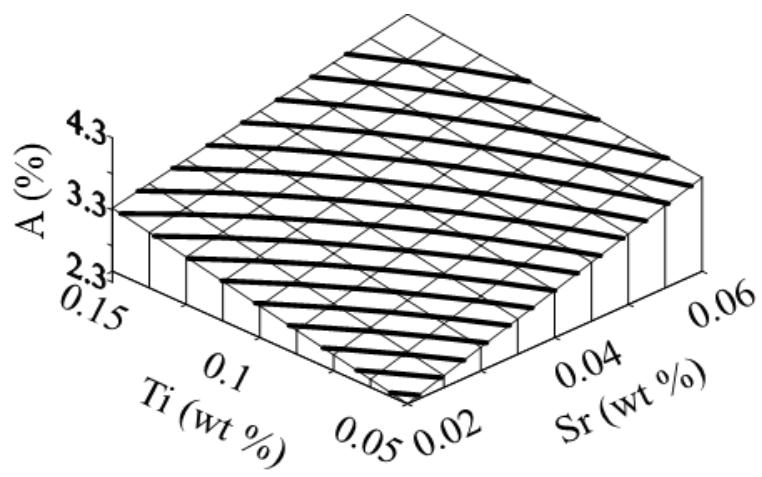

Figure 12 Elongation of AISi9Mg alloy with $\mathrm{Sr}$ within range $<0.02,0.06>(\mathrm{wt} \%)$ and Ti within range $<0.05,0.15>(w t \%)$ for $B=0.02 w t \%$

\section{CONCLUSIONS}

The main conclusion can be written as follows: the use of modifying components ( $\mathrm{Sr}, \mathrm{Ti}, \mathrm{B})$ after initial melting with the main component of the processed alloy $(\mathrm{Al})$ increases elongation more than using the same modifying components $(\mathrm{Sr}, \mathrm{Ti}, \mathrm{B})$ in an unmelted form (powder mix). In addition, it was found that:

- the analysis of the process of hypo-eutectic Al-Si alloy treatment with $\mathrm{Sr}, \mathrm{Ti}$ and $\mathrm{B}$ additions shows that this modifying addition increased plasticity of AISigMg alloy;

- $\quad$ all tested modifiers altered the elongation of the analyzed alloy. The elongations were most significantly modified by borax and strontium with aluminum as an alloy. The analyzed alloy was characterized by more satisfactory plasticity when $\mathrm{Sr}$ or $\mathrm{B}$ were added at $0.06 \mathrm{wt} \%$ and $0.15 \mathrm{wt} \% \mathrm{Ti}$.

Modifying the mechanical properties of silumin is of great importance for many industries, including machine industry [21], thermally sustainable construction [22], construction of tribological pairs [23], construction of recovery devices [24]. The obtained dataset is also a valuable inspiration to improve the predictive models, especially the non-parametric ones $[25,26]$.

\section{REFERENCES}

[1] MACHUTA, J., NOVÁ, I., KEJZLAR, P. Structure and mechanical properties of aluminum alloys AISi10 and AISi5Mg. Manuf. Technol. 2017, vol. 17, pp. 772-777.

[2] HREN, I., SVOBODOVA, J. Fractographic analysis of strontium-modified Al-Si alloys. Manuf. Technol. 2018 , vol. 18, pp. 900-905.

[3] LYSONKOVA, I., NOVOTNY, J., CAIS, J., MICHNA, S. Effect of addition of nanoparticles TiO ${ }_{2}$ into PTFE coating. Engineering for Rural Development. 2017, vol. 16, pp. 26-30.

[4] LIPIŃSKI, T. The structure and mechanical properties of Al-7\%SiMg alloy treated with a homogeneous modifier. Solid State Phenomena. 2010, vol. 163, pp. 183-186. 
[5] LIPIŃSKI, T. SZABRACKI, P. Modification of the hypo-eutectic Al-Si alloys with an exothermic modifier. Arch. Metall. Mater. 2013, vol. 58, no. 2, pp. 453-458.

[6] NOVA, I., FRAŇA, K., SOLFRONK, P., KORECEK, D., Monitoring the influence of sodium chloride particle size on the physical, mechanical properties and structure of samples of porous aluminium materials. Manufacturing Technology. 2021, vol. 21, no. 1, pp. 109-116.

[7] BOLIBRIICHOVÁ, D., HAJDÚCH, P., BRU゚NA, M. Influence of molybdenum, zirconium and copper on structure of aluminum alloy AISilOMg(Cu) (En Ac-43200). Manufacturing Technology. 2018, vol. 18, pp. 709-718.

[8] PACZ, A. Alloy. US Patent No. GB158827. 1921.

[9] THEILE, W., DUNKEL, E. On the long-term modification of aluminum-siliconalloys. Giesserei, 1966, vol. 23.

[10] MARTINOVSKY, M., MADL, J. The effect of different modifiers on cutting temperature in turning of AISi7Mg0.3 alloy. Manufacturing Technology. 2018, vol. 18, pp. 950-953.

[11] KRAUS, P., NÁPRSTKOVÁ, N., JIROUNKOVÁ, K., CAIS, J., SVOBODOVÁ, J. Effect of heat treatment on the microstructure of the alloy AISi7CrMnCu2.5. Manufacturing Technology. 2018, vol. 18, pp. 935-942.

[12] KUČEROVÁ L., HÁJEK, J., VÍTEK, J. The effect of cryogenic treatment on mechanical properties, wear and corrosion resistance of aluminium alloy AW7075. Manufacturing Technology. 2020, vol. 20, no. 1, pp. 60-65.

[13] LIPIŃSKI, T. Influence of surface refinement on microstructure of Al-Si cast alloys processed by welding method. Manufacturing Technology. 2015, vol. 15, no. 4, pp. 576-581.

[14] PASTIRCAK, R., MARTINEC, D., KANTORIKOVA, E. Influence of semisolid squeeze casting technology on alpha phase and eutectic of AISi7Mg0.3. Manufacturing Technology. 2020, vol. 20, no. 1, pp. 78-83.

[15] LIPIŃSKI, T. Double modification of AISi9Mg alloy with boron, titanium and strontium. Archives of Metallurgy and Materials. 2015, vol. 60, Issue 3b, pp. 2415-2419.

[16] MICHNA, Š., HREN, I., CAIS, J., MICHNOVÁ, L. The research of the different properties and production parameters having Influence on deep-drawing sheets made of AlMg3 alloy. Manufacturing Technology. 2020, vol. 20, no. 3, pp. 347-354.

[17] HREN, I., LUŇÁK, M., KUŚMIERCZAK, S. The formation and elimination of the negative influence of porosity on the properties of the alloy castings AISi10Mg. Manufacturing Technology. 2020, vol. 20, no. 2, pp. 170-176.

[18] KUCHARIKOVÁ, L., TILLOVÁ, E., KRITIKOS, M., UHRÍČIK, M., Švecová, I. Usage of a non-destructive testing technology for assessment of porosity in aluminium casts alloys. Manufacturing Technology. 2020, vol. 20, no. 5, pp. 632-638.

[19] LIPIŃSKI, T. Modification of Al-11\% Si alloy with Cl - based modifier. Manufacturing Technology. 2015, vol. 15, no. 4, pp. 581-587.

[20] CUPRYŚ, R., MAJOR, B., WOŁCZYŃSKI, W. Transition of flake into fibre structure in eutectic Al-Si. Materials Science Forum. 2000, vol. 329-330, pp. 161-166.

[21] ANTOSZ, K., PACANA, A. Comparative analysis of the implementation of the SMED method on selected production stands. Tehnicki Vjesnik. 2018, vol. 25, pp. 276-282.

[22] MAJEWSKI, G., ORMAN, Ł.J., TELEJKO, M., RADEK, N., PIETRASZEK, J., DUDEK, A. Assessment of thermal comfort in the intelligent buildings in view of providing high quality indoor environment. Energies. 2020, vol. 13, art. 1973.

[23] KORZEKWA, J., BARA, M., PIETRASZEK, J., PAWLUS, P. Tribological behaviour of $\mathrm{Al}_{2} \mathrm{O}_{3} /$ inorganic fullerenelike $\mathrm{WS}_{2}$ composite layer sliding against plastic. Int. J. Surf. Sci. Eng. 2016, vol. 10, pp. 570-584.

[24] RADZYMINSKA-LENARCIK, E., ULEWICZ, R., ULEWICZ, M. Zinc recovery from model and waste solutions using polymer inclusion membranes (PIMs) with 1-octyl-4-methylimidazole. Desalin. Water Treat. 2018, vol. 102, pp. 211-219.

[25] PIETRASZEK, J., GADEK-MOSZCZAK, A., RADEK, N. The estimation of accuracy for the neural network approximation in the case of sintered metal properties. Studies in Computational Intelligence. 2014, vol. 513, pp. $125-134$.

[26] SZCZOTOK, A., PIETRASZEK, J., RADEK, N. Metallographic study and repeatability analysis of $\mathrm{Y}^{\prime}$ phase precipitates in cored, thin-walled castings made from IN713C superalloy. Arch. Metall. Mater. 2017, vol. 62, pp. $595-601$. 